\title{
Political neutrality in the audit profession: attitudes of respondents in the Republic of Serbia
}

\section{Politička neutralnost u revizorskoj profesiji: stavovi ispitanika u Republici Srbiji}

\author{
Nemanja Jakovljević a $^{*}$ \\ ${ }^{\text {a }}$ State Audit Institution of the Republic of Serbia
}

\begin{abstract}
Political neutrality represents independence from the political activities, as well as from all other activities that can be considered subordinated to direct or indirect political influence. At the individual level, there are two concepts of political neutrality. The subject of this paper is research on the attitudes of respondents engaged in audit profession on political neutrality and challenges to political neutrality. The research was conducted through a survey distributed to the addresses of persons engaged in audit profession in the Republic of Serbia. The main conclusion is that it is necessary to reconsider certain measures to improve the awareness of persons engaged in audit profession on political neutrality, its importance, threats that may violate political neutrality, and protection measures that can be taken at the individual and collective level to preserve political neutrality and audit firms.
\end{abstract}

Keywords: political neutrality, independence, audit, threats, integrity.

Sažetak: Politička neutralnost predstavlja nezavisnost, odnosno izolovanost pojedinca od aktivnosti političkih organizacija, kao $i$ od svih drugih aktivnosti koje se mogu smatrati podređenim direktnom ili indirektnom političkom uticaju. Na individualnom nivou, tačnije posmatrano sa aspekta revizora kao pojedinca, postoje dva koncepta političke neutralnosti. Predmet ovog rada je istraživanje stavova ispitanika koji rade na poslovima revizije o političkoj neutralnosti i izazovima vezanim za političku neutralnost. Istraživanje je sprovedeno putem upitnika distribuiranog na adrese osoba angažovanih na poslovima revizije u Republici Srbiji. Glavni zaključak je da je potrebno preduzeti određene aktivnosti kako bi se poboljšala svest osoba koji rade na poslovima revizije o političkoj neutralnosti, njenom značaju, pretnjama koje mogu narušiti političku neutralnost i merama zaštite koje se mogu preduzeti na individualnom $i$ kolektivnom nivou za očuvanje političke neutralnosti revizora kao pojedinca i revizorske kompanije.

Ključne reči: politička neutralnost; nezavisnost, revizija, pretnje, integritet.

\footnotetext{
${ }^{*}$ Corresponding author

E-mail adress: jakovljevic.i.nemanja@gmail.com
}

This is an open access paper distributed under the license c() (1) (9) 


\section{Introduction}

Political neutrality in the audit profession is a very important factor of stability. Auditors which are responsible for providing an independent and objective opinion should not be politically influenced. Susceptibility to political influence can lead to a loss of audit independence and audit integrity at both the individual and collective levels in the context of audit firms and audit institutions. Those engaged in conducting audit engagements should maintain their political neutrality at a high level, not only during the conduct of the audit engagement but constantly throughout their entire professional career in the audit profession. In this context, the political neutrality of persons engaged in audit profession could be defined as their willingness to remain immune and independent of any internal or external influence that has a political character. It can be realized in two dimensions, political independence of the mind and political independence in appearance. The political independence of the mind is a state of mind of a person engaged in audit profession that implies independence from political influence. It is, in fact, the auditor's view of his political neutrality. Political neutrality in appearance represents the perception of other persons, other stakeholders about their view and position on the political neutrality of the person engaged in audit profession or on the political neutrality of the audit firm. A person engaged in audit profession, especially those in senior positions, should not attend private or public gatherings of political organizations, for any purpose. They should never speak publicly, never discuss political topics, and they should never represent the political views and interests of certain political organizations, either secretly or publicly. Only such an approach can preserve political independence in the appearance of a specific person engaged in audit profession. This is especially important for audit managers in the public sector, who are expected to be especially careful, and who is responsible for doing the work they do in the interests of all citizens, and not one specific political organization.

In defining political neutrality, we can say that there are two sources of influence on the political neutrality of persons engaged in audit profession, namely internal and external. Internal influence is the influence that comes from the person who is engaged in audit profession that comes from his satisfaction or dissatisfaction with the political situation in the country or the world and the desire to influence it. External influence comes from sources outside the reach of the person engaged in the audit profession, but who may influence it directly or indirectly. These can be written and digital media, colleagues, everyday events, and more. Both influences can have a strong influence on the political neutrality of the person engaged in audit profession, and for political neutrality to be truly preserved, it must be preserved from both internal and external influence. If a person engaged in audit profession preserves internal independence from political influence and does not preserve external independence. If he preserves external independence from political influence and does not preserve internal independence, then it cannot be said that a particular person is politically neutral, because both sources are intertwined and affect each other. It is necessary to achieve neutrality from both sources to consider that the person engaged in audit profession is truly politically neutral. 
In most countries, the supreme audit institutions for the audit of the public sector have the legal authority to conduct audits with publicly registered political organizations. This audit is mainly an audit of financial statements or an audit of compliance with business regulations in the field of labor legislation and other areas. When conducting this type of audit, special care should be taken and communication with the responsible persons in the audited entity should be reduced to the necessary minimum and limited exclusively to the topics that are the subject of the audit engagement. Any other type of communication, outside the scope of the audit engagement, can be very risky and can pose an open and direct threat to the independence of the person involved in the audit engagement. Preventive activities to protect auditors from political influence are crucial and should be unequivocally implemented before starting an audit engagement. These may include testing the independence of members of the audit team for political influence and taking corrective action if such influence is observed. A person who is determined in preliminary activities to be subject to political influence in a particular audit engagement may be preventively excluded from the audit team in question and assigned to another audit team where he will not be at risk of being subject to political influence. More frequent control is of great importance in these types of audits and may during the implementation of the audit engagement indicate possible omissions of persons involved in the implementation of the audit engagement. Punishing or removing them from the audit team in question may have the effect of preventing the occurrence of large-scale problems and may have prevented the influence of political representatives on the audit opinion and the audit report. Supreme audit institutions for the audit of the public sector should maintain their neutrality and independence from political influence. If they lose these qualities, then they have no reason to exist and spend state money, because they have lost the trust of the citizens. If they want to have integrity and credibility, the supreme audit institutions for auditing the public sector should not advocate for political power and should not have any connection with politics or politicians.

Auditors in the supreme audit institutions responsible for auditing the public sector are those who work closely with the legislature, the executive, or other governmental bodies authorized by law to review their reports. Where auditors undertake or wish to undertake policy activities, they must bear in mind the effect that their engagement may have, or they appear to have on the ability to perform their professional duties impartially. If auditors are allowed to participate in policy activities, they must be aware that these activities may lead to professional conflict. In the Republic of Serbia, the State Audit Institution of the Republic of Serbia is responsible for conducting the audit in political organizations. It has adopted and publicly published a code of ethics for state auditors, which emphasizes that it is very important for the State Audit Institution to maintain political neutrality because it cooperates with legislative and executive authorities as bodies authorized by law to review its reports (Etički kodeks za državne revizore i druge zaposlene u Državnoj revizorskoj instituciji). State auditors and other employees are obliged to behave politically neutral and to preserve the political neutrality of the State Audit Institution in the performance of their activities (Kodeks ponašanja državnih službenika, p. 2).

A relevant number of auditors in the Republic of Serbia in the public sector have the qualification of a civil servant, which according to them (Kodeks ponašanja državnih 
službenika, p. 2), obliges them to adhere to the principles of political neutrality at all times and not to wear or highlight the features of political organizations or to share with other persons their advertising material, either in paper or electronic form, in the premises where they perform their work tasks. A civil servant must not influence the political orientation of other civil servants and state employees, nor put pressure on them in connection with support for political parties, or political entities that have candidates in elections. A civil servant may not use public gatherings in which he participates and meetings he holds as a civil servant to promote political parties, or political entities or for public representation of election participants and their election programs, or inviting voters to vote or not to vote for certain participants. The public funds entrusted to him in the performance of his duties may not be used by a civil servant for the promotion of political parties, which in particular means the use of official premises, vehicles, and inventory for a political campaign (Kodeks ponašanja državnih službenika, p. 2).

When considering the political neutrality of persons engaged in audit profession, the concept of individual and collective political neutrality can be determined, which is also important for understanding the overall political neutrality in the audit profession. Individual political neutrality is the political neutrality of a specific, person engaged in audit profession. Collective political neutrality is the political neutrality of the collective (the audit firm). It represents the sum of the individual political neutralities of all persons engaged in audit profession in one audit firm. Collective political neutrality can also be at a level lower than the level of the audit firm and this can be the department level or the team level. If it is a question of political neutrality at the level of the audit department, then it represents the sum of individual political neutralities of all persons engaged in audit profession in one audit department, for example, the political neutrality of the audit department responsible for conducting audits in banks. If it is a question of political neutrality at the level of the audit team, then it represents the sum of individual political neutralities of all persons engaged in audit profession in one audit team, for example, the political neutrality of audit team number 2 responsible for conducting the audit in $\mathrm{ABC}$.

The subject of the research in this paper is the examination of the political neutrality of persons engaged in audit profession in the Republic of Serbia. The research was conducted by creating a questionnaire on the topic of examining and determining the degree of political neutrality of persons engaged in audit profession in the Republic of Serbia. The questionnaire contained eight simple questions, of which the first question was created to collect information on the age structure of the respondents through the answers, and the remaining seven questions were created to determine the political neutrality of the respondents. The research aims to determine whether the political neutrality of persons engaged in audit profession in the Republic of Serbia is at a satisfactory level by calculating the coefficient of political neutrality based on the results of the conducted questionnaire. The initial hypothesis from which the research was conducted is that persons engaged in audit profession in the Republic of Serbia have a satisfactory level of political neutrality. 


\section{Literature review}

The available literature on the topic of political neutrality of auditors is very scarce. In private audit firms, it is generally the executive board that oversees communication activities with political organizations. Private audit firms may face the risk of providing consulting services to political organizations for monetary compensation. They can lead to a breach of the political neutrality of those engaged in audit profession and therefore extra caution is needed in such cases. Private audit firms generally have adopted codes of ethics or codes of conduct that regulate, among other things issues of political neutrality of persons engaged in audit profession. All partners and all employees must adhere to the Code. They are generally prohibited from making monetary donations to political organizations and are not allowed to give monetary donations to other parties representing a third party in the name and on behalf of the audit firm. On the other hand, they may be allowed to provide services to political organizations that do not have a financial basis, and therefore additional attention is needed in this area because of such type of cooperation with political organizations and a special type of risk to political neutrality of auditors. The authors (Sian et al., 2020) believe that political attitudes that have a radical character can also affect the status of persons engaged in audit profession, citing the example of Saudi Arabia, where large audit companies that were the subject of research have a significantly higher number of male employees' persons to females, which according to the authors is a consequence of political and national attitudes towards women. The authors (Malsch \& Morin, 2017) analyzed the challenges surrounding the position of Auditor General while emphasizing the importance of his/her personality in the election to the position. They believe that the power of the Auditor General does not expand simply in a set of structures, networks, and discourses, but is embodied in individuals whose power to act and make strategic decisions can bring significant changes (Guenin-Paracini et al., 2015).

The authors (Gendron et al., 2007) believe that the scientist and the auditor are always politicians, trying to claim that their knowledge and expertise are relevant and important, and not guided by their interest, but by universal truths and public interest. The authors (Malsch \& Morin, 2017) believe that the selection of the Auditor General should not be based only on technical auditing skills, although they are very important and a necessary condition for selection, should include communication skills, behavior, and ability to make strategic decisions. The impact of education policy is significant on the audit profession from a general perspective (Hornbeck \& Malin, 2019). The authors (Grasso \& Sharkansky, 2001) consider that the understanding of audit independence seems to be outdated. The author (Avwokeni, 2016) found that the resistance of politicians and employees is a major factor hindering the implementation of program budgeting that affects both audit practice and the auditor's operational activities.

The authors (Amin et al., 2021) investigated the influence of political ties measured according to directors who had previously held political positions on determining audit prices. Their study highlights how auditors understand political relationships and their impact on the quality of financial reporting. Namakavarani (2021) investigated the relationship between the characteristics of the audit committee and the quality of 
accounting information about the role of the internal information environment and political connections. They believe that there is a significant and positive link between the audit committee and the characteristics of the quality of financial information in high-level political relations, as well as between the financial profession and the quality of financial information. Bradney (2001) investigated the arguments of the Quality Assurance Agency to improve the quality of teaching and the ideology of educational audit in the UK and presented the potential impact on reducing the amount of knowledge in external audit and the relationship with teaching quality. The authors (Sutopo et al., 2017) believe that local governments have an important role in providing services, but that some local governments still show relatively low performance, which may be due to the influence of political factors which is reflected in the audit opinion. Accountability policies and enforcement models help to explain the causes of ineffective internal audit legislation and their poor enforcement (Schwarz \& Sulitzeanu-Kenan, 2002). Power (1993) considered the impact of policy on the regulatory allocation of responsibilities and the gap between public demands on auditor's and practitioners' attitudes about their roles and capabilities. There is a significant impact of human rights policy on audit subjects and indirectly on auditors (McGrogan, 2018).

Badaracco (1988) believes that the revision of communication, the traditional technique of business research, and the "new tool" have been the subject of some debate. The revision of communication seems to be political in some ways and other new techniques are not. By "political" it means challenging the fundamental assumptions about what public relations is for what they should do and what organizational role practitioners should play. At the same time, the audit of communications brings public relations closer, as a discipline and a body of knowledge closer to the communication of management. Their article describes a series of views on the role, scope, and purpose of the audit. The authors (Wahab et al., 2011) consider that a unique environment that offers clear and recognizable segments based on ethical norms, whereby management in companies that have strong political ties generally receive special privileges. Research participants (Usang \& Basariah, 2018) pointed out the reasons for the negative relationship between cooperation and the performance of internal and external audits which include the political interest of the external auditor as one of the important reasons.

\section{Empirical data and analysis}

The aim of the research that is the subject of this paper is to examine and determine the degree of political neutrality of persons engaged in audit profession in the Republic of Serbia. The questionnaire contained eight questions and they are presented below in the form of a matrix of research questions

Table 1. Matrix of the research questions

\begin{tabular}{|c|c|c|}
\hline Text of the question & Purpose of the question & $\begin{array}{c}\text { Number of } \\
\text { the } \\
\text { question }\end{array}$ \\
\hline How old are you? & $\begin{array}{l}\text { Determine the age structure of the } \\
\text { respondents. }\end{array}$ & Question 1 \\
\hline
\end{tabular}


Table 1. Continued

\begin{tabular}{|c|c|c|}
\hline Text of the question & Purpose of the question & $\begin{array}{l}\text { Number of } \\
\text { the } \\
\text { question }\end{array}$ \\
\hline $\begin{array}{l}\text { Is anyone in your family a } \\
\text { member of a political party? }\end{array}$ & $\begin{array}{l}\text { Determine if someone from the respondent's } \\
\text { family is a member of a political party. }\end{array}$ & Question 2 \\
\hline $\begin{array}{l}\text { Have you ever actively } \\
\text { discussed political issues } \\
\text { with your colleagues? }\end{array}$ & $\begin{array}{l}\text { To determine whether respondents have ever } \\
\text { actively discussed political issues with } \\
\text { colleagues. }\end{array}$ & Question 3 \\
\hline $\begin{array}{l}\text { Have you ever advocated } \\
\text { the position of a political } \\
\text { party in front of your } \\
\text { colleagues? }\end{array}$ & $\begin{array}{l}\text { To determine whether the respondents have } \\
\text { ever represented the position of a political } \\
\text { party in front of their colleagues. }\end{array}$ & Question 4 \\
\hline $\begin{array}{l}\text { Have you praised the views } \\
\text { of certain politicians in front } \\
\text { of your colleagues? }\end{array}$ & $\begin{array}{l}\text { To determine whether the respondents spoke } \\
\text { praisefully in front of their colleagues about } \\
\text { the attitudes of certain politicians. }\end{array}$ & Question 5 \\
\hline $\begin{array}{l}\text { Have you ever discussed } \\
\text { political issues with an audit } \\
\text { client? }\end{array}$ & $\begin{array}{l}\text { To determine whether respondents have ever } \\
\text { discussed political issues with the audit client. }\end{array}$ & Question 6 \\
\hline $\begin{array}{l}\text { Have you ever advocated } \\
\text { the position of a political } \\
\text { party before an audit client? }\end{array}$ & $\begin{array}{l}\text { To determine whether respondents have ever } \\
\text { represented the position of a political party } \\
\text { before an audit client. }\end{array}$ & Question 7 \\
\hline $\begin{array}{l}\text { Have you praised the views } \\
\text { of certain politicians in front } \\
\text { of the audit client? }\end{array}$ & $\begin{array}{l}\text { To determine whether the respondents spoke } \\
\text { praisefully in front of the audit client about } \\
\text { the attitudes of certain politicians. }\end{array}$ & Question 8 \\
\hline
\end{tabular}

Source: Author

The research conducted as part of this paper contains limitations that have partially influenced the reduction of its scope and the quantitative and qualitative scope of its results, which have nevertheless maintained a satisfactory level of innovation and qualitative perception of knowledge. The first limitation is because the respondents may not have been completely honest when answering the questions from the distributed survey, which can create a distorted picture of the final results and affect the level of interest whose calculation is based on the results of the research. The second limitation is a consequence of the appearance of a limited number of answers in the form of feedback to the questions from the questionnaire which was distributed to the selected respondents via social networks. A larger number of answers would provide greater support and certainty to the presented conclusions and findings, but despite this limitation, the presented conclusions have satisfactory and appropriate support in the results of the questionnaire. Due to all the above, it is necessary to take the presented data with a great deal of caution during their interpretation and their official use. However, despite the stated limitations, the research conducted as a result presented significant findings and conclusions in the field of political neutrality of persons engaged in audit profession in the Republic of Serbia. External audit companies and internal audit departments can use the results of this research as a guide and concept for maintaining and improving the political neutrality of audit engagements to increase overall work performance and accumulated knowledge and practical skills to perform day-to-day tasks. 
The initial hypothesis from which the research was started is that the persons engaged in audit profession in the Republic of Serbia are politically neutral. To collect answers to the questions from the questionnaire, a total of 100 respondents who were engaged in audit profession in the Republic of Serbia were selected, and the questionnaire was distributed to them through available publicly available channels in the form of social networks. Before receiving the questionnaire, the respondents were divided into five groups according to age structure, namely 20 respondents aged between 18 and 27, 20 respondents aged between 28 and 37, 20 respondents aged between 38 and 47, 20 respondents aged age between 48 and 57 years and the remaining 20 respondents are aged between 58 and 67 years. The questionnaire contained eight questions. It was possible to answer each of the remaining five questions with three types of answers, yes, maybe, and no. Answers with that are numerically marked as number 1 for statistical analysis, answers with are not marked with 2 , and answers with may be marked with 3 . The obtained answers were used to calculate the coefficient of political neutrality of persons engaged in audit profession in the Republic of Serbia. The coefficient of political neutrality (CoAPN) is calculated according to the following formula.

CoAPN $=0.3 * \mathrm{q}_{1}+0.1 * \mathrm{q}_{2}+0.1 * \mathrm{q}_{3}+0.1 * \mathrm{q}_{4}+0.1 * \mathrm{q}_{5}+0.1 * \mathrm{q}_{6}+0.1 * \mathrm{q}_{7}$

The values of q represent the cumulative values of the answers to the questions for each question separately, in such a way that the answers with yes are evaluated with 0 points, the answers with maybe evaluated with 0.5 points, and the answers with not evaluated with 1 point. The maximum value of the coefficient of political neutrality of persons engaged in audit profession is 18 points, and the minimum value is 0 points.

\section{Results and Discussion}

The first group of respondents between the ages of 18 and 27 has a coefficient of political neutrality of 13.6 points. The results of the descriptive analysis and the collected answers are given in the following two tables.

Table 2. Frequencies and descriptive statistics of the first group of questions

\begin{tabular}{lccccccc}
\hline Group I & $\mathrm{q} 2$ & $\mathrm{q} 3$ & $\mathrm{q} 4$ & $\mathrm{q} 5$ & $\mathrm{q} 6$ & $\mathrm{q} 7$ & $\mathrm{q} 8$ \\
\hline Valid & 20 & 20 & 20 & 20 & 20 & 20 & 20 \\
Missing & 0 & 0 & 0 & 0 & 0 & 0 & 0 \\
Mean & 2,05 & 1,70 & 2,10 & 1,90 & 2,00 & 1,85 & 2,00 \\
Std. Error of & 0,185 & 0,164 & 0,161 & 0,191 & 0,145 & 0,150 & 0,162 \\
Mean & $2,07^{\mathrm{a}}$ & $1,65^{\mathrm{a}}$ & $2,13^{\mathrm{a}}$ & $1,86^{\mathrm{a}}$ & $2,00^{\mathrm{a}}$ & $1,82^{\mathrm{a}}$ & $2,00^{\mathrm{a}}$ \\
Median & $2^{\mathrm{b}}$ & 1 & 2 & 1 & 2 & 2 & 2 \\
Mode & 0,826 & 0,733 & 0,718 & 0,852 & 0,649 & 0,671 & 0,725 \\
Std. Deviation & 0,682 & 0,537 & 0,516 & 0,726 & 0,421 & 0,450 & 0,526 \\
Variance & $-0,098$ & 0,553 & $-0,152$ & 0,204 & 0,000 & 0,177 & 0,000 \\
Skewness & 0,512 & 0,512 & 0,512 & 0,512 & 0,512 & 0,512 & 0,512 \\
Std. Error of & $-1,518$ & $-0,834$ & $-0,880$ & $-1,617$ & $-0,279$ & $-0,548$ & $-0,931$ \\
Skewness & 0,992 & 0,992 & 0,992 & 0,992 & 0,992 & 0,992 & 0,992 \\
Kurtosis & & & & & & \\
Std. Error of & Kurtosis & & & & & &
\end{tabular}


To the second question, 4 respondents answered with yes, 14 answered with no, and 2 answered with maybe. To the third question, 7 respondents answered with yes, 12 answered with no, and 1 answered with maybe. To the fourth question, 4 respondents answered with yes, 13 answered with no, and 3 answered with maybe. To the fifth question, 5 respondents answered with yes, 10 answered with no, and 5 answered with maybe. To the sixth question, 1 respondent answered with yes, 17 answered with no, and 2 answered with maybe. To the seventh question, 1 respondent answered with yes, 16 answered with no, and 3 answered with maybe. To the eighth question, 2 respondents answered with yes, 14 answered with no, and 4 answered with maybe.

Table 3. Answers of the first group of respondents

\begin{tabular}{lccccccc}
\hline Sum of answers from group I & $\mathrm{q} 2$ & $\mathrm{q} 3$ & $\mathrm{q} 4$ & $\mathrm{q} 5$ & $\mathrm{q} 6$ & $\mathrm{q} 7$ & $\mathrm{q} 8$ \\
\hline Count of yes $* 0$ & 0 & 0 & 0 & 0 & 0 & 0 & 0 \\
Count of no $* 1$ & 14 & 12 & 13 & 10 & 17 & 16 & 14 \\
Count of maybe *0,5 & 1 & 0,5 & 1,5 & 2,5 & 1 & 1,5 & 2 \\
$\mathrm{q}$ & 15 & 12,5 & 14,5 & 12,5 & 18 & 17,5 & 16 \\
$0,3(0,1) \mathrm{x} \mathrm{q}$ & 4,5 & 1,25 & 1,45 & 1,25 & 1,8 & 1,75 & 1,6 \\
Coefficient of the political neutrality & 13,6 & & & & & & \\
\hline
\end{tabular}

Source: Author based on the received answers

Another group of respondents aged between 28 and 37 has a coefficient of political neutrality of 12.5 points. The results of the descriptive analysis and the collected answers are given in the following two tables.

Table 4. Frequencies and descriptive statistics of the second group of questions

\begin{tabular}{lccccccc}
\hline Group II & $\mathrm{q} 2$ & $\mathrm{q} 3$ & $\mathrm{q} 4$ & $\mathrm{q} 5$ & $\mathrm{q} 6$ & $\mathrm{q} 7$ & $\mathrm{q} 8$ \\
\hline Valid & 20 & 20 & 20 & 20 & 20 & 20 & 20 \\
Missing & 0 & 0 & 0 & 0 & 0 & 0 & 0 \\
Mean & 2,35 & 2,00 & 2,15 & 2,15 & 2,15 & 2,20 & 2,20 \\
Std. Error of & 0,150 & 0,178 & 0,150 & 0,182 & 0,109 & 0,117 & 0,138 \\
Mean & $2,39^{\mathrm{a}}$ & $2,00^{\mathrm{a}}$ & $2,18^{\mathrm{a}}$ & $2,20^{\mathrm{a}}$ & $2,16^{\mathrm{a}}$ & $2,21^{\mathrm{a}}$ & $2,22^{\mathrm{a}}$ \\
Median & $2^{\mathrm{b}}$ & 2 & 2 & 3 & 2 & 2 & 2 \\
Mode & 0,671 & 0,795 & 0,671 & 0,813 & 0,489 & 0,523 & 0,616 \\
Std. Deviation & 0,450 & 0,632 & 0,450 & 0,661 & 0,239 & 0,274 & 0,379 \\
Variance & $-0,549$ & 0,000 & $-0,177$ & $-0,296$ & 0,442 & 0,294 & $-0,120$ \\
Skewness & 0,512 & 0,512 & 0,512 & 0,512 & 0,512 & 0,512 & 0,512 \\
Std. Error of & $-0,548$ & $-1,366$ & $-0,548$ & $-1,399$ & 1,304 & 0,457 & $-0,207$ \\
Skewness & 0,992 & 0,992 & 0,992 & 0,992 & 0,992 & 0,992 & 0,992 \\
Kurtosis & & & & & & & \\
Std. Error of & Kurtosis & & & &
\end{tabular}

Source: Author based on analysis of results using SPSS

To the second question, 2 respondents answered with yes, 9 answered with no, and 9 answered with maybe. To the third question, 6 respondents answered with yes, 8 answered with no, and 8 answered with maybe. To the fourth question, 3 respondents answered with yes, 11 answered with no, and 6 answered with maybe. To the fifth question, 5 respondents answered with yes, 7 answered with no, and 8 answered with maybe. To the sixth question, 1 respondent answered with yes, 15 answered with no, and 4 answered with maybe. To the seventh question, 1 respondent answered with yes, 
14 answered with no, and 5 answered with maybe. To the eighth question, 2 respondents answered with yes, 12 answered with no, and 6 answered with maybe.

Table 5. Answers of the second group of respondents

\begin{tabular}{lccccccc}
\hline Sum of answers from group II & $\mathrm{q} 2$ & $\mathrm{q} 3$ & $\mathrm{q} 4$ & $\mathrm{q} 5$ & $\mathrm{q} 6$ & $\mathrm{q} 7$ & $\mathrm{q} 8$ \\
\hline Count of yes $* 0$ & 0 & 0 & 0 & 0 & 0 & 0 & 0 \\
Count of no $* 1$ & 9 & 8 & 11 & 7 & 15 & 14 & 12 \\
Count of maybe *0,5 & 4,5 & 3 & 3 & 4 & 2 & 2,5 & 3 \\
$\mathrm{q}$ & 13,5 & 11 & 14 & 11 & 17 & 16,5 & 15 \\
$0,3(0,1) \times \mathrm{q}$ & 4,05 & 1,1 & 1,4 & 1,1 & 1,7 & 1,65 & 1,5 \\
Coefficient of the political neutrality & 12,5 & & & & & & \\
\hline
\end{tabular}

Source: Author based on the received answers

The third group of respondents, aged between 38 and 47, has a coefficient of political neutrality of 11.3 points. The results of the descriptive analysis and the collected answers are given in the following two tables.

Table 6. Frequencies and descriptive statistics of the third group of questions

\begin{tabular}{lccccccc}
\hline Group III & $\mathrm{q} 2$ & $\mathrm{q} 3$ & $\mathrm{q} 4$ & $\mathrm{q} 5$ & $\mathrm{q} 6$ & $\mathrm{q} 7$ & $\mathrm{q} 8$ \\
\hline Valid & 20 & 20 & 20 & 20 & 20 & 20 & 20 \\
Missing & 0 & 0 & 0 & 0 & 0 & 0 & 0 \\
Mean & 2,10 & 1,85 & 2,05 & 2,10 & 2,15 & 2,10 & 2,15 \\
Std. Error of & 0,176 & 0,196 & 0,153 & 0,191 & 0,109 & 0,124 & 0,150 \\
Mean & $2,13^{\mathrm{a}}$ & $1,79^{\mathrm{a}}$ & $2,06^{\mathrm{a}}$ & $2,14^{\mathrm{a}}$ & $2,16^{\mathrm{a}}$ & $2,11^{\mathrm{a}}$ & $2,18^{\mathrm{a}}$ \\
Median & 2 & 1 & 2 & 3 & 2 & 2 & 2 \\
Mode & 0,788 & 0,875 & 0,686 & 0,852 & 0,489 & 0,553 & 0,671 \\
Std. Deviation & 0,621 & 0,766 & 0,471 & 0,726 & 0,239 & 0,305 & 0,450 \\
Variance & $-0,186$ & 0,315 & $-0,062$ & $-0,204$ & 0,442 & 0,083 & $-0,177$ \\
Skewness & 0,512 & 0,512 & 0,512 & 0,512 & 0,512 & 0,512 & 0,512 \\
Std. Error of & $-1,308$ & $-1,667$ & $-0,630$ & $-1,617$ & 1,304 & 0,766 & $-0,548$ \\
Skewness & 0,992 & 0,992 & 0,992 & 0,992 & 0,992 & 0,992 & 0,992 \\
Kurtosis & & & & & \\
Std. Error of & Kurtosis & & & & & &
\end{tabular}

Source: Author based on analysis of results using SPSS

To the second question, 5 respondents answered with yes, 8 answered with no, and 7 answered with maybe. To the third question, 9 respondents answered with yes, 5 answered with no, and 6 answered with maybe. To the fourth question, 4 respondents answered with yes, 11 answered with no, and 5 answered with maybe. To the fifth question, 6 respondents answered with yes, 6 answered with no, and 8 answered with maybe. To the sixth question, 1 respondent answered with yes, 15 answered with no, and 4 answered with maybe. To the seventh question, 2 respondents answered with yes, 14 answered with no, and 4 answered with maybe. To the eighth question, 3 respondents answered with yes, 11 answered with no, and 6 answered with maybe. 
Table 7. Answers of the third group of respondents

\begin{tabular}{llllllll}
\hline Sum of answers from group III & $\mathrm{q} 2$ & $\mathrm{q} 3$ & $\mathrm{q} 4$ & $\mathrm{q} 5$ & $\mathrm{q} 6$ & $\mathrm{q} 7$ & $\mathrm{q} 8$ \\
\hline Count of yes * 0 & 0 & 0 & 0 & 0 & 0 & 0 & 0 \\
Count of no 1 & 8 & 5 & 11 & 6 & 15 & 14 & 11 \\
Count of maybe * 0,5 & 3,5 & 3 & 2,5 & 4 & 2 & 2 & 3 \\
$\mathrm{q}$ & 11,5 & 8 & 13,5 & 10 & 17 & 16 & 14 \\
$0,3(0,1)$ x q & 3,45 & 0,8 & 1,35 & 1 & 1,7 & 1,6 & 1,4 \\
Coefficient of the political neutrality & 11,3 & & & & & & \\
\hline
\end{tabular}

Source: Author based on the received answers

The fourth group of respondents, aged between 48 and 57, has a coefficient of political neutrality of 10.9 points. The results of the descriptive analysis and the collected answers are given in the following two tables.

Table 8. Frequencies and descriptive statistics of the fourth group of questions

\begin{tabular}{lccccccc}
\hline Group IV & $\mathrm{q} 2$ & $\mathrm{q} 3$ & $\mathrm{q} 4$ & $\mathrm{q} 5$ & $\mathrm{q} 6$ & $\mathrm{q} 7$ & $\mathrm{q} 8$ \\
\hline Valid & 20 & 20 & 20 & 20 & 20 & 20 & 20 \\
Missing & 0 & 0 & 0 & 0 & 0 & 0 & 0 \\
Mean & 2,15 & 1,95 & 1,95 & 2,10 & 2,05 & 2,05 & 1,95 \\
Std. Error of & 0,182 & 0,185 & 0,153 & 0,191 & 0,135 & 0,135 & 0,153 \\
Mean & $2,20^{\mathrm{a}}$ & $1,93^{\mathrm{a}}$ & $1,94^{\mathrm{a}}$ & $2,14^{\mathrm{a}}$ & $2,06^{\mathrm{a}}$ & $2,06^{\mathrm{a}}$ & $1,94^{\mathrm{a}}$ \\
Median & 3 & $1^{\mathrm{d}}$ & 2 & 3 & 2 & 2 & 2 \\
Mode & 0,813 & 0,826 & 0,686 & 0,852 & 0,605 & 0,605 & 0,686 \\
Std. Deviation & 0,661 & 0,682 & 0,471 & 0,726 & 0,366 & 0,366 & 0,471 \\
Variance & $-0,296$ & 0,098 & 0,062 & $-0,204$ & $-0,012$ & $-0,012$ & 0,062 \\
Skewness & 0,512 & 0,512 & 0,512 & 0,512 & 0,512 & 0,512 & 0,512 \\
Std. Error of & $-1,399$ & $-1,518$ & $-0,630$ & $-1,617$ & 0,189 & 0,189 & $-0,630$ \\
Skewness & 0,992 & 0,992 & 0,992 & 0,992 & 0,992 & 0,992 & 0,992 \\
Kurtosis & & & & & & \\
Std. Error of & Kurtosis & & & & & &
\end{tabular}

Source Author based on analysis of results using SPSS

To the second question, 5 respondents answered with yes, 7 answered with no, and 8 answered with maybe. To the third question, 7 respondents answered with yes, 7 answered with no, and 6 answered with maybe. To the fourth question, 5 respondents answered with yes, 11 answered with no, and 4 answered with maybe. To the fifth question, 6 respondents answered with yes, 6 answered with no, and 8 answered with maybe. To the sixth question, 3 respondents answered with yes, 13 answered with no, and 4 answered with maybe. To the seventh question, 3 respondents answered with yes, 13 answered with no, and 4 answered with maybe. To the eighth question, 5 respondents answered with yes, 11 answered with no, and 4 answered with maybe.

Table 9. Answers of the fourth group of respondents

\begin{tabular}{llllllll}
\hline Sum of answers from group IV & $\mathrm{q} 2$ & $\mathrm{q} 3$ & $\mathrm{q} 4$ & $\mathrm{q} 5$ & $\mathrm{q} 6$ & $\mathrm{q} 7$ & $\mathrm{q} 8$ \\
\hline Count of yes $* 0$ & 0 & 0 & 0 & 0 & 0 & 0 & 0 \\
Count of no $* 1$ & 7 & 7 & 11 & 6 & 13 & 13 & 11 \\
Count of maybe $* 0,5$ & 4 & 3 & 2 & 4 & 2 & 2 & 2 \\
$\mathrm{q}$ & 11 & 10 & 13 & 10 & 15 & 15 & 13 \\
$0,3(0,1)$ x q & 3,3 & 1 & 1,3 & 1 & 1,5 & 1,5 & 1,3 \\
Coefficient of the political neutrality & 10,9 & & & & & & \\
\hline
\end{tabular}

Source: Author based on the received answers 
The fifth group of respondents, aged between 58 and 67, has a coefficient of political neutrality of 10.2 points. The results of the descriptive analysis and the collected answers are given in the following two tables.

Table 10. Frequencies and descriptive statistics of the fifth group of questions

\begin{tabular}{lccccccc}
\hline Group V & $\mathrm{q} 2$ & $\mathrm{q} 3$ & $\mathrm{q} 4$ & $\mathrm{q} 5$ & $\mathrm{q} 6$ & $\mathrm{q} 7$ & $\mathrm{q} 8$ \\
\hline Valid & 20 & 20 & 20 & 20 & 20 & 20 & 20 \\
Missing & 0 & 0 & 0 & 0 & 0 & 0 & 0 \\
Mean & 2,05 & 1,70 & 2,10 & 1,90 & 2,00 & 1,85 & 2,00 \\
Std. Error of & 0,185 & 0,164 & 0,161 & 0,191 & 0,145 & 0,150 & 0,162 \\
Mean & $2,07^{\mathrm{a}}$ & $1,65^{\mathrm{a}}$ & $2,13^{\mathrm{a}}$ & $1,86^{\mathrm{a}}$ & $2,00^{\mathrm{a}}$ & $1,82^{\mathrm{a}}$ & $2,00^{\mathrm{a}}$ \\
Median & $2^{\mathrm{b}}$ & 1 & 2 & 1 & 2 & 2 & 2 \\
Mode & 0,826 & 0,733 & 0,718 & 0,852 & 0,649 & 0,671 & 0,725 \\
Std. Deviation & 0,682 & 0,537 & 0,516 & 0,726 & 0,421 & 0,450 & 0,526 \\
Variance & $-0,098$ & 0,553 & $-0,152$ & 0,204 & 0,000 & 0,177 & 0,000 \\
Skewness & 0,512 & 0,512 & 0,512 & 0,512 & 0,512 & 0,512 & 0,512 \\
Std. Error of & $-1,518$ & $-0,834$ & $-0,880$ & $-1,617$ & $-0,279$ & $-0,548$ & $-0,931$ \\
Skewness & 0,992 & 0,992 & 0,992 & 0,992 & 0,992 & 0,992 & 0,992 \\
Kurtosis & & & & & & & \\
Std. Error of & Kurtosis & & &
\end{tabular}

Source: Author based on analysis of results using SPSS

To the second question, 6 respondents answered with yes, 7 answered with no, and 7 answered with maybe. To the third question, 9 respondents answered with yes, 8 answered with no, and 3 answered with maybe. To the fourth question, 4 respondents answered with yes, 10 answered with no, and 6 answered with maybe. To the fifth question, 8 respondents answered with yes, 6 answered with no, and 6 answered with maybe. To the sixth question, 4 respondents answered with yes, 12 answered with no, and 4 answered with maybe. To the seventh question, 6 respondents answered with yes, 11 answered with no, and 3 answered with maybe. To the eighth question, 5 respondents answered with yes, 10 answered with no, and 5 answered with maybe.

Table 11. Answers of the fifth group of respondents

\begin{tabular}{lccccccc}
\hline Sum of answers from group V & $\mathrm{q} 2$ & $\mathrm{q} 3$ & $\mathrm{q} 4$ & $\mathrm{q} 5$ & $\mathrm{q} 6$ & $\mathrm{q} 7$ & $\mathrm{q} 8$ \\
\hline Count of yes * 0 & 0 & 0 & 0 & 0 & 0 & 0 & 0 \\
Count of no 1 & 7 & 8 & 10 & 6 & 12 & 11 & 10 \\
Count of maybe * 0,5 & 3,5 & 1,5 & 3 & 3 & 2 & 1,5 & 2,5 \\
$\mathrm{q}$ & 10,5 & 9,5 & 13 & 9 & 14 & 12,5 & 12,5 \\
$0,3(0,1) \times \mathrm{q}$ & 3,15 & 0,95 & 1,3 & 0,9 & 1,4 & 1,25 & 1,25 \\
Coefficient of the political neutrality & 10,2 & & & & & & \\
\hline
\end{tabular}

Source: Author based on the received answers

Based on the presented analysis, it can be concluded that the coefficient of political neutrality of persons engaged in audit profession decreases as the age of the respondent's increases. The coefficient of political neutrality has a maximum value of 18 points. A value of 0 points indicates that there is a complete political bias of persons engaged in audit profession. A value in the range of 0 to 4 points indicates that there is very low political neutrality. A value in the range of 4 to 8 points indicates that there 
is low political neutrality. A value in the range of 8 to 12 points indicates that there is moderate political neutrality, a value in the range of 12 to 16 indicates that there is high political neutrality and a value of 16 to 20 points indicates that there is very high political neutrality.

Graph 1. Coefficient of the auditor's political neutrality

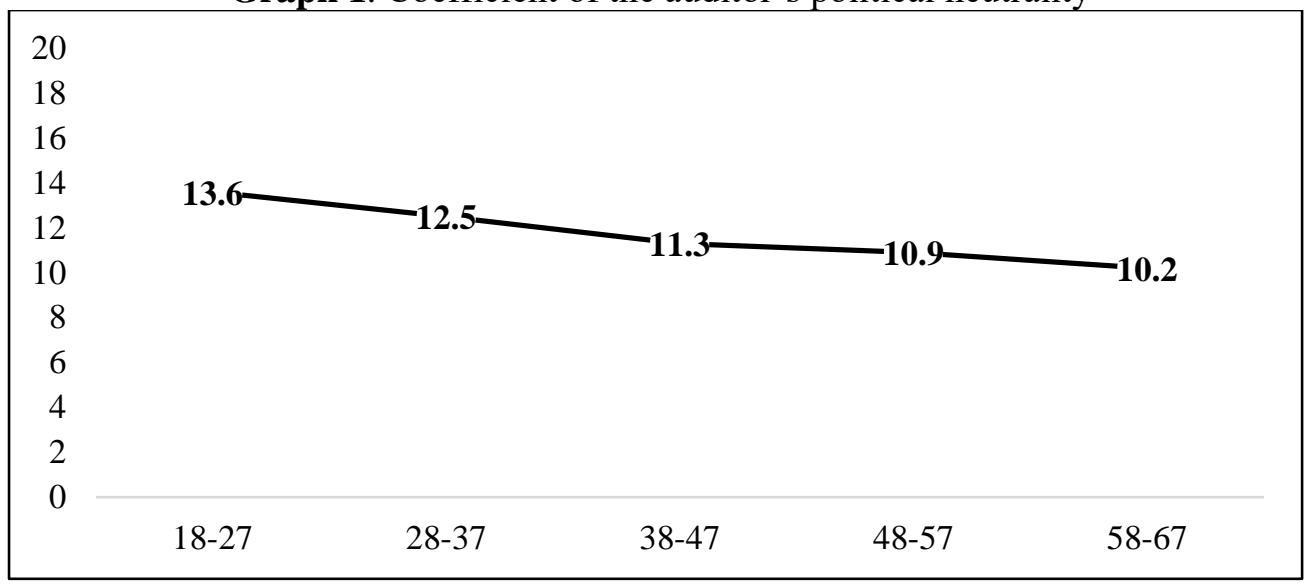

Source: Author

In the Republic of Serbia, the respondents who participated in the research and represent persons engaged in audit profession have a high level of political impartiality between the ages of 18 and 37 and moderate political bias between the ages of 38 and 67.

\section{Conclusion}

Political neutrality represents the independence, isolation of an individual from the activities carried out by political organizations, as well as from all other activities that can be considered subordinated to direct or indirect political influence. At the individual level, from the aspect of the auditor as an individual, there are two concepts of political neutrality. Both concepts are equally important, and for the auditor to be truly politically neutral, he must unconditionally fulfill both concepts at all times, and especially during the period of implementation of a specific audit engagement. The participation of political representatives in the activities carried out by audit teams engaged in audit profession and related activities can lead to temporary or in severe cases and to permanent loss of reputation of certain auditors, which can significantly affect the entire audit profession.

Essentially, political neutrality from the point of view of the international aspect is an area that is extremely complicated for a single regulation at the supranational level. This is largely due to the diversity in the types of political organization between different countries, as well as differentiated cultural understandings that may include different views on political neutrality and the obligation to apply it by representatives of the audit profession. Active participation in the implementation of the audit engagement in different countries may have different threats based on the political neutrality of auditors and may cause the need to apply different measures in response 
to them. Certain states have a broad and uncompromising application of freedom of speech, human and minority rights, and civil rights guaranteed by constitutional norms or other highest legal norms, while other states do not.

It is of great importance that each person engaged in audit profession, as well as persons engaged in work that helps the smooth functioning of the audit profession, work daily to preserve both real and projected political neutrality, individually from the auditor's point of view and collectively observed aspect of the audit firm. While preserving their neutrality, auditors also preserve the collective political neutrality, the political neutrality of the audit firm. It is therefore important that each auditor maintains his or her neutrality to external political influences, to be able to adequately conduct any audit engagement with positive and successful results, and to be able to provide independent and objective assurance. Generally, before each audit engagement, the persons engaged in the audit profession sign a statement of ethical independence, which should, among other things, test their political neutrality during the audit in question.

Auditors must maintain their neutrality to political influence to perform their audit activities impartially. Where auditors wish to undertake policy activities, they must bear in mind the effect that their engagement may have or appears to have on the ability to perform their professional duties impartially. Auditors may not be allowed to participate in political activities, they must be aware that these activities may lead to professional conflict and sanctions provided for in the Rules on Disciplinary Responsibility. Employees of supreme institutions for the audit of public funds in the performance of their functions must be independent and autonomous to the legislative, executive, and judicial branches, the media, citizens' associations, electronic media, advertising on websites, public figures, or other persons and to perform the function independently of any external influence, restriction, persuasion, pressure or threat following its assessment of the evidence and interpretation of legal norms. By their conduct, persons engaged in audit profession must maintain and strengthen public confidence in the independence in the performance of their duties, and in particular refrain from expressing political views and public appearances of a political nature, appearances in which offensive content is presented, except in cases of participation in discussions directly related to an audit engagement, from attending political rallies or from participating in any way in political campaigns.

Respondents aged between 18 and 27 have a coefficient of political neutrality of 13.6 points, which means that they have a very high political neutrality. Respondents aged between 28 and 37 have a coefficient of political neutrality of 12.5 points, which means that they have a very high political neutrality. Respondents between the ages of 38 and 47 have a coefficient of political neutrality of 11.3 points, which means that they have moderate political neutrality. Respondents between the ages of 48 and 57 have a coefficient of political neutrality of 10.9 points, which means that they have moderate political neutrality. Respondents aged between 58 and 67 have a coefficient of political neutrality of 10.2 points, which means that they have moderate political neutrality, too. In the Republic of Serbia, respondents who participated in the survey and represent persons engaged in audit profession have high political impartiality between the ages of 18 and 37 and a moderate political between the ages of 38 and 67, 
which suggests that the political neutrality of those engaged on audit profession in the Republic of Serbia is at a satisfactory level. The main conclusion is that it is necessary to reconsider certain measures to improve the awareness of persons engaged in audit profession on political neutrality, its importance, threats that may violate political neutrality, and protection measures that can be taken at the individual and collective level to preserve political neutrality and audit firms.

\section{References}

Amin, K., Kim, C., Yang, Z., \& Ye, F. (2021). Politically connected boards and audit pricing: US Evidence. Accounting Horizons, 35(3), 1-22. https://doi.org/10.2308/HORIZONS-18-157

Avwokeni, A. J. (2016). Cultural resistance, output measures, and audit practice: impact on non-implementation of program-based budgeting in Nigeria. International Journal of Public Administration, 39(12), 909-916. https://doi.org/10.1080/01900692.2015.1057850

Badaracco C. (1988). The Politics of Communication Audits, Public Relations Quarterly, 33(3), 27-32;

Bradney, A. (2001). The Quality Assurance Agency and the politics of audit. Journal of Law and Society, 28(3), 430-442. https://doi.org/10.1111/1467-6478.00197

Kodeks ponašanja državnih službenika. Službeni glasnik RS, br. 29/2008, 30/2015, 20/2018, 42/2018, 80/2019 i 32/2020;

Etički kodeks za državne revizore i druge zaposlene u Državnoj revizorskoj instituciji. Službeni glasnik RS, br. 44/2009;

Gendron, Y., Cooper, D. J., \& Townley, B. (2007). The construction of auditing expertise in measuring government performance. Accounting, Organizations and Society, 32(1-2), 101-129. https://doi.org/10.1016/j.aos.2006.03.005

Grasso, P. G., \& Sharkansky, I. (2001). The auditing of public policy and the politics of auditing: The US GAO and Israel's state comptroller. Governance, 14(1), 121. https://doi.org/10.1111/0952-1895.00149

Guénin-Paracini, H., Malsch, B., \& Tremblay, M. S. (2015). On the operational reality of auditors' independence: Lessons from the field. Auditing: A Journal of Practice \& Theory, 34(2), 201-236. https://doi.org/10.2308/ajpt-50905

Hornbeck, D., \& Malin, J. (2019). State auditors in education policy. Educational Policy, 33(7), 1047-1075. https://doi.org/10.1177\%2F0895904818755469

Malsch, B., \& Morin, D. (2017). Legislative audit, at the frontiers of power and politics. Accounting Auditing Control, 23(1), 75-96. https://doi.org/10.3917/cca.231.0075

McGrogan, D. (2018). The population and the individual: The human rights audit as the governmentalization of global human rights governance. International Journal of Constitutional Law, 16(4), 1073-1100. https://doi.org/10.1093/icon/moy086

Namakavarani, O. M., Daryaei, A. A., Askarany, D., \& Askary, S. (2021). Audit Committee Characteristics and Quality of Financial Information: The Role of the Internal Information Environment and Political Connections. Journal of Risk and Financial Management, 14(6), 273. https://doi.org/10.3390/jrfm14060273 
Power, M. (1993). The politics of financial auditing. The Political Quarterly, 64(3), 272-284. https://doi.org/10.1111/j.1467-923X.1993.tb00344.x

Scwartz, R., \& Sulitzeanu-Kenan, R. (2002). The politics of accountability: Institutionalising internal auditing in Israel. Financial Accountability \& Management, 18(3), 211-231. https://doi.org/10.1111/1468-0408.00151

Sian, S., Agrizzi, D., Wright, T., \& Alsalloom, A. (2020). Negotiating constraints in international audit firms in Saudi Arabia: exploring the interaction of gender, politics and religion. Accounting, Organizations and Society, 84, 101103. https://doi.org/10.1016/j.aos.2020.101103

Sutopo, B., Wulandari, T. R., Adiati, A. K., \& Saputra, D. A. (2017). E-government, audit opinion, and performance of local government administration in Indonesia. Australasian Accounting, Business and Finance Journal, 11(4), 622. http://dx.doi.org/10.14453/aabfj.v11i4.2

Usang Edet Usang, O., \& Salim, B. (2018). The relationship between institutional environment, internal audit and performance of local governments in Nigeria. International Journal of Accounting and Finance (IJAF), 7(2), 120147.

Wahab, E. A. A., Zain, M. M., \& James, K. (2011). Political connections, corporate governance and audit fees in Malaysia. Managerial Auditing Journal, 26(5), 393-418. https://doi.org/10.1108/02686901111129562

Received: 23 September, 2021; Revised: 4 October, 2021; Accepted: 19 October, 2021.

Rad je primljen: 23.09.2021. Korigovan: 01.10.2021. Prihvaćen: 19.10.2021. 